\title{
The SEC's Ectoplasmic Theory of an Issuer as Applied to Educational and Charitable Institutions, Bank Trustees, and Other Exempt Issuers
}

\author{
Robert C. Hacker ${ }^{\dagger}$ \\ Ronald D. Rotunda it
}

\begin{abstract}
This Article discusses the background and development of the SEC'S "ectoplasmic" theory and, as an illustrative case study, provides a detailed analysis of its application to pooled income fund trusts maintained by charitable and educational institutions. The authors also consider the implications of the theory for another type of pooled investment fund maintained by charitable and educational institutions -the qualified pooled pension plan. They both discuss the current $S E C$ position in this area and suggest further action the Commission should take.
\end{abstract}

The federal securities laws grant banks, insurance companies, and charitable and educational institutions certain exemptions froin their registration requirements. The Securities and Exchange Commission (SEC) has created a "double entity" or "ectoplasmic" theory of an issuer, however, to strip these institutions of their traditional exemptions in a variety of circumstances. Because of the flexibility of the theory, it has become an important tool of the SEC in regulating certain investment activities conducted by otherwise exempt issuers; it has had equally important implications under the federal banking laws. In a recent instance ${ }^{1}$ the "double entity" theory operated to deny colleges and universities that inaintained qualified pooled income fund trusts the educational organization's exemptions ${ }^{2}$ from registration under the

$\dagger$ A.B., University of Illimois, 1962; J.D., University of Illinois, 1965. Member of the Washington, D.C. and Illinois bars.

ti Associate Professor, University of Illinois College of Law. A.B., Harvard University, 1967; J.D., Harvard Law School, 1970. Member of the New York, Washington, D.C., and Illinois bars.

The authors thank Ms. Vicki Thompson for her helpful assistance.

1. "No Action" Letter of Dec. 14, 1972 to American Council on Education, [1972-73 Transfer Binder] FED. SEC. L. REP. (CCH) Tा 79,179, reprinted at note 107 infra.

2. These trusts were, however, granted another exemption. See note 107 infra. 
Securities Act of $1933^{3}$ (the 1933 Act) and the Investment Company Act of $1940^{4}$ (the 1940 Act).

\section{The "Ectoplasmic" or "Double Entity" Theory OF AN ISSUER}

The double entity theory origmated in connection with the SEC's requirement that American Depositary Receipts (ADR's) be registered. ${ }^{5}$ An ADR is a negotiable receipt issued by a domestic bank certifying that a foreign security has been deposited abroad with the bank's foreign branch or custodian. ${ }^{6}$ ADR's closely resemble American share certificates and are usually issued agamst deposits of underlying shares on a share for share basis. When foreign shares are traded at a low U.S. price, however, each ADR may represent a block of foreign shares. ${ }^{7}$ The Ainerican bank collects the dividends on the foreign shares, converts the foreign exchange into American dollars, and forwards these dollars to the holders of the ADR's. For these services the bank charges a fee; other fees are assessed for issuance and withdrawal of the ADR's. ${ }^{8}$ ADR's relieve the American investor of much of the inconverience of trading in foreign securities. ${ }^{9}$

In the ADR's early years, depositary banks countered any attempt to require thein to register their ADR's under the 1933 Act by claiming that the receipts were bank-issued securities and thus exempt under section 3(a)(2). ${ }^{10}$ The SEC staff accepted this interpretation as late as the early 1950's, and allowed banks to issue ADR's without registration if

3. 15 U.S.C. $\$ \$ 77 \mathrm{a}-77 \mathrm{aa}$ (1970) [hereinafter referred to as the 1933 Act].

4. 15 U.S.C. $\$ \$ 80 a-1$ to $80 a-52$ (1970 \& Supp. V 1975) [hereinafter referred to as the 1940 Act].

5. See generally Moxley, The ADR: An Instrument of International Finance and a Tool of Arbitrage, 8 VILL. L. REv. 19 (1962) [hereinafter cited as Moxley].

6. Id. at 22-24; Note, S.E.C. Regulation of American Depositary Receipts: Disclosure Ltd., 65 YALE L.J. 861, 863-64 (1956); see generally Legal Problems of Issuing and Marketing Foreign Securities in the United States (Panel Discussion), in INTERNATIONAL FinanCing aND INVESTMENT 430 (J. McDaniels ed. 1964).

7. Thus, one Hitachi ADR represents 80 underlying shares, while one Leslie Gold Mines ADR represents 5 underlying shares. Hardy, How ADRs Will Infiltrate Portfolios, Com. \& Fin. Chronicle, April 29, 1974, at 28, col. 2.

8. Fountain, American Depositary Receipts and their Uses, Fin. ANALYSTS J., Jan.-Feb. 1969, at 15.

9. See generally Moxley, supra note 5, at 20-21; Note, S.E.C. Regulation of American Depositary Receipts: Disclosure Ltd. 65 YALE L.J. 861, 861-62 (1956). Guaranty Trust Co. of New York originated the first ADR in 1927. Morgan Guaranty Trust, its successor, is the leading issuer of ADR's, with more than 209 ADR's in January, 1975. Morgan Guaranty Trust Co., ADR-IDR (July 1974) (updated) (on file with the California Law Review).

10. 15 U.S.C. $\$ 77 \mathrm{c}(\mathrm{a})(2)(1970)$. 
the underlying shares could be sold without registration. ${ }^{11}$ In 1955 the Irving Trust Company announced that it would issue ADR's against deposits of some thirty-four issuers on the London exchange and one Dutch issuer, all without registration. ${ }^{12}$ It became apparent that the special status granted to bank-issued ADR's had created a significant loophole in the 1933 Act's registration scheme. The SEC therefore announced that the section 3(a)(2) exemption from registration would no longer be available for ADR's issued by a depositary bank. ${ }^{13}$

Since the section 3(a)(2) exemption is statutory, however, the SEC could not simply proclaim it unavailable. In order to dance around the strictures of the statute, the Commission created what is now often called the double entity or ectoplasimic theory of an issuer. Under this theory, the section 3(a)(2) exemption for bank-issued securities was unavailable for ADR's which the bank proposed to issue to investors, because the bank was not really the issuer. In the SEC's view:

To permit a bank to claim this exemption for any trust or similar entity that it might devise would permit the creation of voting trusts, investment trusts and a variety of other securities for which the disclosure requirements of the Securities Act of 1933 could be avoided. ${ }^{14}$

The SEC, accordingly, determined that the issuer of ADR's was not the depositary bank, but a "fictitious" entity, the account, and that this account was subject to the registration requirement of the 1933 Act. $^{15}$ This is true even though the bank is required to sign the registration statement on behalf of the fictitious entity. ${ }^{16}$ The theory has come to be called the ectoplasmic theory of an issuer because the second entity, the account, is a fiction or ghost, an ectoplasm.

The SEC again turned to the double entity theory in the variable annuity insurance cases. The variable annuity contract was developed by imsurance companies to provide a medium for investment in equity securities accompanied by annuity guarantees. It differs from traditional annuity contracts because it substitutes a promise to pay a varymg amount for the usual promise to pay a certain ainount. Instead, the contract purchaser is entitled to receive payments measured by the

11. See Moxley, supra note 5, at 29. Loss].

12. 1 L. Loss, Securities Regulation 565 (2d ed. 1961) thereinafter cited as

13. See Official Report of Proceedings Before the Securities and Exchange Commission, Conference on American Depositary Receipts, June 20, 1955, Securities Act Release No. 3593 (Nov. 17, 1955).

14. 22 SEC ANNUAL REPORT 43 (1956).

15. Id.

16. See 1 Loss, supra note 12 , at 565 n.22. 
fluctuating market value of his pro rata share of a portfolio of equity securities, the variable annuity account, maintained by the insurance company.

The SEC took the position that the variable annuity account maintained by the insurance company rather than the insurance coinpany itself was the issuer of the variable annuity contracts for purposes of the 1933 and 1940 Acts. The separate account was thus deemed an investment company subject to the 1940 Act, and the msurance company-an exempted issuer under Section 3(c)(3) of the 1940 Actwas deemed the sponsor, underwriter and investment adviser of the separate mvestment company. The Third Circuit affirmed the Commission's position, ${ }^{17}$ and, in SEC $v$. Variable Life Insurance Co., ${ }^{18}$ the Supreme Court validated the double entity theory of an issuer as applied to the variable annuity accounts of insurance companies. ${ }^{10}$

A sequel to the SEC's successful effort to require registration of variable annuity separate accounts began in April of 1963. The Comptroller of the Currency revised its regulations to permit a national bank to have a collective trust fund that contamed commingled funds and was managed by the bank in a capacity other than as trustee, executor, administrator or guardian. ${ }^{20}$ Such a collective trust fund was known as a commingled managing agency account. The SEC asserted that such a managing agency account was an issuer separate froin the bank itself and that the exemptions from the 1933 and 1940 Acts for banks and securities issued by banks were not available for this separate account. In the SEC's view, the 1933 Act required that units of interest

17. Prudential Ins. Co. v. SEC, 326 F.2d 383 (3d Cir.), cert. denied, 377 U.S. 953 (1964).

18. 359 U.S. 65 (1959); see also SEC v. United Benefit Life Ins. Co., 387 U.S. 202 (1967); Variable Life Ins. Co., 39 S.E.C. 680 (1960).

19. The Commission thereafter applied the same double entity theory to variable life insurance contracts by withdrawing Rule 3c-4 under the 1940 Act. This Rule had defined the term "insurance company" (which is an exempt issuer) to include a separate account which was employed as the funding medium for variable life insurance contracts, thereby, in effect, withdrawing the exemption of such separate accounts under the 1940 Act. Investment Co. Act Release No. 8826 (July 30, 1975). The Commission determined to withdraw the exemptive rule and make such variable life accounts subject to regulation under the 1940 Act because the continuation of the rule had been contingent upon the development of state insurance regulations covering such accounts comparable to regulations that would have been applicable under the 1940 Act and such comparable regulations had not been developed under state law. Investment Co. Act Release No. 8690 (February 27, 1975).

20. Commingling of managing agency accounts under the fiduciary powers of national banks was first authorized in 1963. 28 Fed. Reg. 3309 (1963) (codified in 12 C.F.R. $\$ 9.18$ ). The comptroller issued this new regulation after Congress transferred regulatory responsibility for the fiduciary activities of national banks from the Federal Reserve Board to the Comptroller, P.L. No. 87-722, 76 Stat. 668 (1962) (codified at 12 U.S.C. $\$ 92 a(1970)$ ). 
in the account be registered and the 1940 Act compelled the managing agency account itself to register, since the units of interest would be publicly offered to bank customers who would obtain an undivided imterest in a portfolio of equity securities maintained by the bank, just as does the purchaser of a mutual fund share or a variable annuity contract. $^{21}$

In 1965, the First National City Bank proposed to establish a commingled managing agency account pursuant to the applicable regulations of the Comptroller of the Currency. Funds in the account were to be invested principally in a portfolio of common stocks. The bank would serve as investment adviser and custodian for the account, would execute all transactions and would be underwriter of the account's units of imterest within the meaning of the 1940 Act. No broker or dealer would be engaged to underwrite or distribute participations in the account and neither sales load nor redemption charges would be imposed. The account registered as an investment company under the 1940 Act and filed a registration statenient pursuant to the 1933 Act. Accordingly, the SEC granted exemptions froin various provisions of the 1940 Act to allow the First National City Bank to operate the account. ${ }^{22}$

In September 1967 the Investment Company Institute filed a complaint against the Comptroller of the Currency asking the court to set aside the Comptroller's regulation and approval of commingled managing agency accounts, on the ground that the Comptroller had unlawfully authorized activities violating provisions of the Glass-Steagall Act, ${ }^{23}$ which was designed to divorce the commercial banking business from the securities business. The Supreme Court in Investment Company Institute v. Camp ${ }^{24}$ ultimately held that First National City Bank's commingled managing agency account was prohibited by sections 16 and 21 of the Glass-Steagall Act. ${ }^{25}$

After the Camp case, First National City Bank instituted a different investment plan, the Special Investment Advisory Service (SIAS), which did not involve the poolimg of investment accounts in the conventional sense. Rather, each customer's funds were held in a segregated SIAS account and each account was invested in seven or eight securities; however, the selection of securities was the same for all new

21. Bank Collective Investment Funds, Securities Act Release No. 4589, Investment Co. Act Release No. 3648 (1963).

22. See National Ass'n of Sec. Dealers, Inc. v. SEC, 420 F.2d 83 (D.C. Cir. 1969) (per curiam), rev'd sub nom. Investment Co. Inst. v. Camp, 401 U.S. 617 (1971).

23. Banking Act of 1933, Pub. L. No. 66-89, 48 Stat. 184 (1933) (codified in scattered sections of 12 U.S.C., chapters 2,3, and 6 (1970)).

24. 401 U.S. 617 (1971).

25. 12 U.S.C. $\$ \$ 24,378(1970)$. 
accounts invested at any given time. In all other respects the accounts were handled as normal customer accounts held in custody of a broker. In February 1970, the SEC brought injunctive proceedings against First National City Bank and Merrill Lynch, Pierce, Fenner and Smith, Inc., alleging a violation of the registration requirements of the 1933 and 1940 Acts in the operation of SIAS. To avoid the exemptions from registration for a bank and securities issued or guaranteed by a bank, the SEC coinplaint used the double entity theory to treat SIAS as a separate issuer. SIAS was alleged to be an "investment company" since its accounts, although maintained separately, were effectively pooled through common investment in the same securities. The SEC also alleged that SIAS was an "issuer" of "securities," in the form of discretionary trading authorizations, for purposes of the 1933 Act. SIAS was even made a judicial person by being named a defendant in the complaint. The controversy was resolved by a stipulation and a consent order of the District Court which effected the discontinuance of SIAS. ${ }^{20}$

Application of the double entity theory is not limited to business organizations, however. Its concepts can also be applied to pooled income fund trusts maintained by charitable and educational institutions.

\section{II}

\section{The Pooled Income Fund Trust}

For many years private colleges and universities have sought substantial gifts froin well-to-do benefactors by arranging to pay the donors the income generated by their gifts during their lives, with the entire fund vesting unconditionally in the donee at the time of the donor's death. ${ }^{27}$ Often a bank serves as the trustee of this pooled trust fund.

26. SEC Litigation Release No. 4534 (Feb. 6, 1970).

27. For example, a typical college solicitation recently announced to its alumni: There are ... a number of ways of giving now while retaining the income for life and the life of another, such as a spouse [or an only child]. . . . Alumni interested in retaining a life income may wish to consider one of these methods. Assets which have increased in value over their cost are particularly attractive for a gift of this kind.

Letter from William Schofield, Chairman of the Planned Giving Program of the Har. vard Law School Fund to "Dear Fellow Graduate" (January, 1975) (copy on file with the California Law Review). See Moffitt, Some Charitable Donations Can Earn Income For the Giver, Wall St. J., Dec. 20, 1976, at 26, col. 1:

The pooled-income vehicle for non-profit instructions was devised for Pomona College unore than 20 years ago by Leonard S. Shelton, a Pomona lawyer who later became a director of the [Nationall Audubon [Society] and helped start its fund in 1972. Harvard, Yale and Wheaton College of Illinois, among others, offer such funds. And so do a few other institutions, including the Audubon, the YMCA and the Memorial Sloan-Kettering Center for Cancer Research. ... .

Since 1972, the Audubon fund has grown to $\$ 631,000$. The money has 
All three parties to the arrangement benefit. The benefactor securcs immediately both the psychic pleasure of donating money for charitable purposes and the more tangible pleasures of a life estate in the income of the donated corpus and certain tax deductions. ${ }^{28}$ The educational institution benefits by securing a vested remainder imterest immediately rather than only the possibility of a place in the donor's will sometime in the perhaps distant future. The bank obtains the various fees typically paid to the trustee of a trust fund. ${ }^{29}$

The neat arrangement, however, raises important issues under the various securities acts ${ }^{30}$ and related banking law problems under the Glass-Steagall Act. ${ }^{31}$ Under the double entity theory, the arrangement arguably creates a fund separate from the donee institution. The fund itself then issues, for value, a security-the promise of a life income interest in the separate fund. If the donor's life income interest is a "security," the solicitation of donors to contribute to such a fund without prior registration of the interests under the 1933 Act may constitute a public offering of the security in violation of section 5 of the Act. ${ }^{32}$ Further, the separate fund may be an investment company subject to the 1940 Act. Considering the fund a separate entity may also raise Glass-Stea-

come from 40 contributors, only one of whom has died; that death gave the society $\$ 3,800$. Contributions have ranged between the minimum $\$ 1,000$ and $\$ 107,000$.... A gift [of securities] sometimes offers especially attractive tax advantages in avoiding capital gains and keeping large sums out of taxable estates.

The [Audubon] fund is currently yielding its participants $7.5 \%$ on the market value of their shares in it. Morgan Guaranty [Trust, the manager] tries to keep the return as close to $8 \%$ as possible. The money is largely invested in corporate bonds.

28. These unique charitable vehicles are not appealing investment mediums for the average investor because the benefactor takes only an interest in the life estate; the college has a vested interest in the remainder. On the other hand, this vehicle does have appeal for people who desire income during their lifetime but have no other obligations which require the principal after their death, as for example, a childless widow.

29. To secure these fees banks, it appears, will solicit small colleges to encourage them to set up pooled income fund trusts. This solicitation or touting creates special Glass-Steagall problems. Investment Co. Inst. v. Camp, 401 U.S. 617, 634 (1971). See text accompanying notes 94-103 infra. It also raises special securities problems. See text accompanying notes 104-105 infra.

30. This Article is primarily concerned with the problems arising under the 1933 Act, 15 U.S.C. $\S \S 77 \mathrm{a}-77 \mathrm{aa}$ (1970) and the 1940 Act, 15 U.S.C. $\$ \S 80 \mathrm{a}-1$ to $80 \mathrm{a}-$ 52 (1970 \& Supp. V 1975).

31. Banking Act of 1933, Pub. L. No. 66-89, 48 Stat. 184 (1933) (codified in scattered sections of 12 U.S.C., chapters 2, 3, and 6 (1970)). See generally Note, Commingled Investment Accounts: Banks v. Securities Industry, 45 NoTRE DAME LAW. 746 (1970).

32. Section 5 states: "(a) Unless a registration statement is in effect as to a security, it shall be unlawful for any person, directly or indirectly-(1) to make use of any means or instrument of transportation or commumication in interstate commerce or the mails to sell such security . . .." 15 U.S.C. $\$ 77$ e (1970). 
gall Act issues if the fund has a bank trustee. Under Investment Company Institute v. Camp, ${ }^{33}$ the bank's functions as a "trustee" of the pooled incoine trust fund inight violate section 16 of the Glass-Steagall Act, ${ }^{34}$ which prohibits a national bank froin underwriting any issues of securities and from purchasing any such securities for its own accounts, and section 21 of the Act, ${ }^{35}$ which prohibits a national bank from engaging in the business of issuing, underwriting, selling, or distributing stocks or securities.

\section{A. Structure of the Pooled Income Fund Trust}

Prior to 1969 , life income fund trusts took a number of different forms. In soine cases the donee college merely included the donor's gift in its general endowment fund and promised to pay the donor the average yearly rate earned by its endowment. In other cases the gifts were commingled with similar gifts in a separate pooled fund and the donee college promised to pay the donor or his beneficiaries the average yearly rate of return earned by the pooled fund. In 1969 important revisions in the Internal Revenue Code placed severe restrictions on the form of such pooled income fund trusts. Although these statutory and regulatory restrictions do not provide significant additional revenue for the government, ${ }^{36}$ they have closed a number of loopholes ${ }^{37}$ and provide significant protection for the investor. The Tax Reform Act of $1969^{38}$ anended section 170(f)(2)(A) of the Internal Revenue Code of 1954 to permit a charitable contribution deduction for a gift to an eligible charity of a remainder interest in trust only if the trust is (1) a fixed annuity trust, ${ }^{39}$ (2) a unitrust, ${ }^{40}$ or (3) a pooled incoine fund trust described in section 642(c)(5) of the Code. This Article discusses only trusts regulated by section 642 .

33. 401 U.S. 617 (1971).

34. 12 U.S.C. \& $24(1970)$.

35. 12 U.S.C. § $378(1970)$.

36. See S. Rep. No. 91-552, 91st Cong., 1st Sess. 13 (1969), indicating that tax fairness rather than only raising revenue was an important consideration in the tax reforms: "The fact that present law permits a small minority of high-income individuals to escape tax on a large proportion of their income has seriously undermined the belief of taxpayers that others are paying their fair share of the tax burden."

37. Myers, Charitable Contributions, 4 IND. LEGAL F. 217, 242 (1970).

38. Pub. L. No. 91-172, 83 Stat. 487 (1969) (codified in scattered sections of the Internal Revenue Code).

39. A fixed annuity trust is one which specifies that a fixed dollar amount be paid annually to the noncharitable income beneficiary.

40. A unitrnst is one in which the amount of the annual distribution to the noncharitable income beneficiary is a fixed percentage of the annual valuation of the trnst's assets, so that the amount of distribution fluctuates with the appreciation of, or the decrease in, the asset value of the trust. 
Under section 642, a pooled incoine fund trust may be maintained only by designated public cliarities. ${ }^{41}$ Each donor must transfer an irrevocable remainder interest in the property donated, subject only to a life incoine interest for one or more living persons. ${ }^{42}$ The fund commingles the property transferred by many such donors; ${ }^{43}$ no other properties inay be included in the trust. ${ }^{44}$ The properties of the trust, however, inay be commingled with other properties, such as the endowment fund of a college or university, so long as there is sufficient accounting to identify the assets of the pooled trust and the income allocable to them. ${ }^{45}$ The regulations require that the donee institution control the pooled trust. The institution inay either exercise control directly, by acting as trustee, or imdirectly, by naming an entity such as a bank to serve as trustee, but retaining the power to remove the trustee and name a substitute. ${ }^{46}$ Although the property donated to the trust may consist of money, securities, or other properties, ${ }^{47}$ the pooled trust usually lolds its assets in the form of an investment portfolio consisting generally of marketable securities.

\section{B. The Application of the 1933 Act}

The definition of a security given by section 2(1) of the 1933 Act probably encompasses a donor's life income interest in a pooled income

41. A public charity eligible to maintain such a pooled trust is defined in section $624(c)(5)$ as a college, church, hospital, governmental unit or publicly supported and operated institution. Such an institution is defined in the first six clauses of I.R.C. $\S 170$ (b)(1)(A).

42. Treas. Reg. $\S 1.642(c)-5(b)(1)$ (1971). The instrument that creates the life interest must specify at the time of the transfer of property to the trust the particular beneficiary or beneficiaries to whom the income is payable and the share of income distributable to each person so specified. Id. $\$ 1.642$ (c)-5(b)(2).

43. Id. $\$ 1.642(\mathrm{c})-5(\mathrm{~b})(3)$. Each transfer of property to a pooled trust apparently is a separate trust fund under the Code, however, so that a pooled trust actually contains numerous individual life income trusts.

44. Id. In addition, upon the termination of an income interest, by death or otherwise, the trustee must sever from the pooled trust an amount equal to the value of the remainder interest in the property upon which the income interest is based. This amount must either be paid to, or retained for the benefit of, the public charity entitled to the remainder interest under the governing instrument of the trust. The value of the interest so severed must be either (1) its value as of the determination date next succeeding the termination of the income interest, or (2) its value as of the date on which the last regular payment was made before the death of the income beneficiary, if the income interest is terminated on that payment date. Id. $\$ 1.642(\mathrm{c})-$ 5(b) (8). On determination dates, see notes 130-131 infra and accompanying text.

45. Id. § $1.642(\mathrm{c})-5(\mathrm{~b})(3)$.

46. Id. $\$ 1.642(\mathrm{c})-5(\mathrm{~b})(5)$. The Regulations also provide detailed rules governing other aspects of the trust: income allocation among beneficiaries, see note 114 infra and accompanying text; the amount of the charitable contribution deduction permitted the donor, see note 113 infra and accompanying text; and the dates on which trust assets inust be valued, see notes 130-131 infra and accompanying text.

47. No contributions of tax-exempt securities may be made, however. Id. $\S 1.642$ (c) $-5(b)$ (4). 
trust fund. That section defines security to include, among other things, any "investinent contract." 48 The elements of an investment contract are well established, ${ }^{48}$ and were perhaps best stated in the classic case of SEC v. W. J. Howey Co. ${ }^{50}$ In Howey the Supreme Court applied the 1933 Act to a contract under which one party purchased a lot in an orange grove and contracted with another to manage it for his profit. The Court there described an investment contract as:

[A] contract, transaction or scheme whereby a person invests his money in a common enterprise and is led to expect profits solely from the efforts of the promoter or a third party, it being immaterial whether the shares in the enterprise are evidenced by formal certificates or by nominal interests in the physical assets employed in the enterprise. ${ }^{51}$

Life incoine interests in pooled income fund trusts should fall within this broad test. A donor invests money (in the form of a charitable contribution) in a common enterprise (the pooled fund) and is led to expect profits (froin the generation of income by the fund's investments) solely from the efforts (in the form of investment portfolio manageinent) of the promoter or a third party (the donee institution and its retained investment manager, the bank). Indeed, life income interests are similar to shares in a typical mutual fund, except that the donor cannot redeem the charitable contribution or the appreciation in the contribution's value. Although the donor's inability to recover the contributed principal makes the pooled income trust fund somewhat unattractive as a vehicle for investment, the donor nevertheless appears to "invest" in the future performance of the fund.

A more debatable issue is whether a contribution to a pooled incoine fund trust involves the "sale" for "value" required under the 1933 Act. Section 2(3) defines "sale" to include "every contract of sale or disposition of a security or interest in a security, for value." ${ }^{\prime 2}$ A bona fide gift does not normally involve a sale. ${ }^{53}$ Conceptually, a transfer of property to a pooled trust imvolves only the transfer by the donor of a remainder interest in the property. The donor retains the life interest im the income generated by the property. Accordingly, the

48. 1933 Act $\S 2(1), 15$ U.S.C. $\$ 77$ (b) (1) (1970).

49. See, e.g., SEC v. United Benefit Life Ins. Co., 387 U.S. 202 (1967); SEC v. W. J. Howey Co., 328 U.S. 293 (1946); SEC v. C. M. Joiner Leasing Corp., 320 U.S. 344 (1943); Los Angeles Trust Deed \& Mortgage Exch. v. SEC, 285 F.2d 162 (9th Cir.), cert. denied, 366 U.S. 919 (1961).

50. 328 U.S. 293 (1946).

51. Id. at 298-99.

52. 15 U.S.C. \& $77 b(3)(1970)$.

53. 1 Loss, supra note 12 , at 516 . 
transfer of the remainder interest to the pooled trust is arguably not consideration paid by the donor for the "purchase" of the life income interest. The donor does not "purchase" the life income interest from the pooled trust, for the life income interest never belonged to the trust. Rather, the donor simply retains the life income interest in the transferred property. Since the donor has not purchased anything, the transfer of the remainder interest in property represents a bona fide gift made by the donor. The Internal Revenue Code's treatinent of these transfers buttresses this argument. The Code specifically recognizes that the full amount of the remainder interest in property transferred to a pooled trust constitutes a bona fide gift and, accordingly, allows the donor a charitable deduction for the full value of the reinainder interest. ${ }^{54}$

Although this argument is conceptually appealing, it ignores a critical fact: the entire amount of the contributed property is placed in the hands of the donee institution, which manages the property so that it produces income, or profit, for the donor or the named beneficiary. Indeed, one who donates to a pooled income fund trust is not motivated solely by charitable intent. If that were the case, the donor would either give the entire property immediately or bequeath it to the institution. In fact, the "gift" is made with strings attached because the donor seeks to receive both current income from the property and a prompt tax deduction for the charitable contribution as well as to contribute to the institution. Schools seeking contributions through their pooled trusts do not fail to emphasize these advantages of the income benefits. ${ }^{55}$ Thus, the life income interest retained by the donor represents an investment in the performance of the fund and its management. Under these circumstances, the fund and the donee institution have received "value" in connection with the disposition of a security, in the form of the reinainder interest in the property contributed by the donor. ${ }^{56}$ The courts in the past have not been restrictive in interpreting the "sale" for "value" requirement of the 1933 Act, ${ }^{57}$ and it seems likely that the courts and the SEC would reject any narrow interpretation of "sale."

54. I.R.C. $\S 170(f)(2)(A), 642(c)$.

55. See note 27 supra.

56. In a somewhat similar situation Professor Loss has noted that charitable donees receiving gifts from controlling persons (even where there is no retained life income interest) are sometimes considered to be "underwriters" on the theory that they have "purchased from" them with a view to distribution within the meaning of the 1933 Act. 4 Loss, supra note 12, at 2558.

57. See SEC v. Harwyn Indus. Corp., 326 F. Supp. 943 (S.D.N.Y. 1971), an injunctive suit brought under section 22a of the 1933 Act and section 27 of the 1934 Securities and Exchange Act; Judge Mansfield found that spin-offs by Harwyn "violated the spirit and purpose of the [disclosure] registration requirements of $\$ 5$ 
A more controversial question is whether the double entity theory should be applied to make the pooled income fund trust itself, rather than the donee institution that maintains the trust, the "issuer" of the security represented by the life income interest. ${ }^{58}$ Treating the fund as a separate entity, and thus the issuer, is supported by the provisions of the 1969 Tax Reform Act that require a pooled imcome fund trust to be maintained as a special fund separate from the donee institution's general endowment. ${ }^{59}$ Deterinining who the "issuer" is has closely related collateral consequences under the $1940 \mathrm{Act}^{30}$ as well as direct implications for the application of the 1933 Act.

Section 5(a) of the 1933 Act prohibits any issuer, underwriter, or dealer from selling any security to the public unless a registration statement covering the security is in effect. ${ }^{61}$ As used in the 1933 Act, the term "underwriter" means "any person who has purchased from an issuer with a view to, or offers to sell for an issuer in connection with, the distribution of any security, or participates or has a direct or indirect participation in any such undertaking." 22 Under the double entity interpretation, when a donee institution, directly or through a representative, solicits donors to contribute to its pooled income fund trust, the donee is offering to "sell" for an "issuer" (the pooled fund) in connection with the distribution of a "security," or participating in such an undertaking. In either case, the institution falls within the definition of

of the 1933 Act," and therefore

[w]e see no reason to construe $\S \S 2(3)$ and 5 as requiring that the "value" requiring registration must flow from the immediate parties who received the stock, in this case Harwyn's shareholders. ... When the agreement, spin-off and distribution is viewed as one transaction, there was "value" received by Harwyn and the inside defendants in the form of a contribution of substantially new assets to each subsidiary and the creation of a public market in the shares with its recurring benefits to the defendants, including insiders.

Id. at 953-54. But cf. Truncale v. Blumberg, 80 F. Supp. 387 (S.D.N.Y. 1948) (Medina, J.). When the SEC argued that a charitable gift was a "sale" for purposes of section 16(b) of the 1934 Securities and Exchange Act the Court answered:

On the face of the matter it seems nothing short of absurd to consider these gifts as "sales" within the meaning of Section 16(b). . . .

....

... By no stretch of the imagination . . . can a gift to charity or indeed to anyone else when made in good faith and without pretense or subterfuge, be considered a sale or anything in the nature of a sale. ... To describe these gifts to charity as a "tax dodge," seems nothing short of a gratuitous slur on a man whose benefactions cover such a wide field and so evidence a charitable disposition which the law should foster rather than condemn.

Id. at 389,391 .

58. "Issuer" is defined as a "person" in the 1933 Act and "person" is defined to include a "trust." 15 U.S.C. $\$ \$ 77 b(4),(2)(1970)$.

59. Treas. Reg. $\$ 1.642$ (c) -5(b) (3) (1971).

60. See text accompanying notes 76-81 infra.

61. 15 U.S.C. $\$ 77 \mathrm{e}(\mathrm{a})(1970)$.

62. 15 U.S.C. $\$ 77 b(11)(1970)$. 
"underwriter." Hence, both the fund, as issuer, and the donee institution, as underwriter, would violate section 5 unless the securities had been properly registered, or unless some exemption from the provisions of section 5 were available to the fund and the donee institution. Although three exemptions appear available, application of the double entity theory effectively elimmates all exemptions from the registration provisions of the 1933 Act.

In order to analyze the applicability of the exemptions of the 1933 Act to pooled income fund trusts, the three types of pooled funds that qualify under section 642 (c) (5) of the Internal Revenue Code inust be distinguished: (1) pooled funds for which a bank acts as trustee; (2) pooled funds for which the donee institution acts as trustee and which are maintained as distinct funds separate from the institution's general endowment fund; and (3) pooled funds which are invested jointly with the institution's general endowment fund, but which, for accounting purposes, are sufficiently separated to identify the assets of the pooled fund and the income attributable thereto. The 1933 Act exeinptions must be considered as they apply to each of these categories.

\section{The Charitable Institution Exemption under Section 3(a)(4)}

The exemption available under section 3(a)(4) has two separate requirements: (1) the issuer must be organized "exclusively" for charitable or educational purposes, and (2) no part of its net earnings may inure to any stockholder or private mdividual. ${ }^{63}$ Under the first requirement the exeinption is lost if the issuer has a single, substantial noncharitable, noneducational purpose. ${ }^{64}$ The exeinption is lost under the second requirement if any part of the net earnings of the issuer is used to confer benefits on a determinate group of persons who are investors $\mathrm{m}$, or otherwise have a proprietary interest in, the issuer. ${ }^{65}$ The institution fails the second test even when the benefits conferred on such persons are distributed in furtherance of the issuer's charitable or educational purposes. ${ }^{66}$

If the charitable or educational institution that organizes and maintains a pooled fund is viewed as the issuer of the life income interest therein, it can be argued that the institution meets the two requirements of the exeinption. First, the institution is not organized or oper-

63. 15 U.S.C. $\$ 770(a)(4)$ (1970). The 1940 Act contains a substantially identical exemption. See text accompanying notes 84-86 infra.

64. SEC v. American Found'n for Advanced Educ., 222 F. Supp. 828, 831 (W.D. La. 1963).

65. See id. at 831; SEC v. Children's Hosp., 214 F. Supp. 883 (D. Ariz. 1963); SEC v. United Prosperity Plan, 1 S.E.C. 435 (1937).

66. See SEC v. American Found'n for Advanced Educ., 222 F. Supp. at 831. 
ated for any noncharitable or noneducational purpose; its organization and operation of a pooled income fund are merely imcidental to the carrymg out of its charitable or educational purposes. Second, since the organization and operation of the pooled fund represents a cost of raising funds for the institution to carry out its charitable or educational purposes, no net earnings of the institution inure to the benefit of donors who contribute to the fund.

This "single entity" theory is more appealing where the institution, rather than a bank, serves as trustee of the pooled fund. Similarly, it is easier to view the institution as the issuer where the assets of the pooled fund are invested jointly with the institution's general endowment fund, rather than invested as a separate pool of assets.

If the double entity theory is applied, however, none of the three types of pooled funds will qualify for the exemption for charitable and educational institutions. If the fund is viewed as the issuer, the second requirement cannot be inet, because net earnings of the fund inure to the benefit of a determinate group of persons having a pecuniary interest in the issuer, i.e., the donors or their beneficiaries. Moreover, one purpose of the fund is to provide these benefits-a substantial noneducational purpose.

Sound public policy grounds exist for treating pooled income funds as issuers separate from the donee institutions theinselves in order to subject these funds to the registration, disclosure, and related provisions of the 1933 Act. Donors can be viewed as a class of persons who may need the protections provided by registration. This is particularly true in light of the potential for conflict between the interest of a donee institution in maximizing appreciation of the capital donated to the pooled fund, and the interest of donors in maximizing the incoine generated by such capital. This conflict arises because, generally speaking, the selection of securities to provide inaximum current income return may minimize the potential for capital appreciation, and vice versa ${ }^{67}$ Without the SEC's assertion of at least potential jurisdiction, many donors might not be provided with sufficient information regarding this possible conflict of interest or the actual yield that donors can realistically expect from a contribution to the fund.

\section{The Private Placement Exemption under Section 4(2)}

If the donee institution itself, rather than a bank, acts as trustee

67. See Scudder Duo-Vest, Inc., Supplement dated April 5, 1967 to Prospectus dated March 22, 1967 at 3. For examples of investment policies designed to mitigate the conflict between one person's imterest in maximizing appreciation of invested capital and another's interest in maximizing income yield, see, e.g., Scudder Duo-Vest, Inc., Prospectus, supra. 
of the pooled fund, the only other possible exemption is provided by section 4(2), which states that section 5 shall not apply to "transactions of an issuer not imvolving any public offering." 88 The Supreme Court has determined that the availability of the private placement exemption of section 4(2) "should turn on whether the particular class of persons affected needs the protection of the Act." 69 If the class does not need the protection, the offermg may be considered "private." The principal criterion to be used in establishing whether protection is needed is whether the persons to whom the offering is made have such a relationship with the issuer as to have "access to the same kind of information that the act would make available in the form of a registration statement."70 Typically, prospective donors would not have such a special relationship with a donee institution or its pooled income fund trust as to assure the donor access to the type of information regarding the operations of the fund that registration would provide. Accordingly, neither a pooled income fund trust nor the donee institution that solicits contributions to such a fund could ordinarily rely on the private placement exemption.

\section{The Bank Common Trust Fund Exemption under Section 3(a)(2)}

If a bank serves as trustee for a pooled fund, another exemption under the 1933 Act miglit be available. Section 3(a)(2) of the 1933 Act provides that the provisions of that Act shall not apply to:

[A]ny security issued or guaranteed by any bank ... or any interest or participation in any common trust fund or similar fund maintained by a bank exclusively for the collective investment and reinvestment of assets contributed thereto by such bank in its capacity as trustee, executor, administrator, or guardian. . . . For purposes of this paragraph, a security issued or guaranteed by a bank shall not include any interest or participation in any collective trust fund maintained by a bank. ${ }^{71}$

The express terms of section 3(a)(2) prevent a life income interest issued by a pooled income fund trust from being considered a "security issued" by a trustee bank. Moreover, under the double entity theory the pooled income fund trust, rather than the bank, would be deemed the issuer. ${ }^{72}$

The life income interest might, however, be considered an "interest or participation in any common trust fund or similar fund

68. 15 U.S.C. $\$ 77$ (d) (1970).

69. SEC v. Ralston Purina Co., 346 U.S. 119, 125 (1953).

70. Id. at 125-26. Accord, United States v. Custer Channel Wing Corp., 376 F.2d 675, 678 (4th Cir. 1967).

71. 15 U.S.C. $\$ 77 \mathrm{c}(\mathrm{a})(2)(1970)$.

72. See text accompanying notes 58-60 supra. 
maintained by a bank . . . in its capacity as trustee, executor, administrator or guardian," within the meaning of section $3(a)(2) .^{73}$ The question whether this exemption is available is interwoven with the issue of the status of the pooled income fund trust under the 1940 Act. Unless a pooled incoine fund trust for which a bank serves as trustee is able to qualify for exemption under the 1940 Act, it can not qualify under section 3(a)(2) of the 1933 Act. $^{74}$ Whether a pooled income fund trust is subject to registration as an investment company under the 1940 Act is discussed below. ${ }^{75}$ If the conclusion there that the fund nust register is correct, pooled funds may not claim the section 3(a)(2) exemption under the 1933 Act.

\section{The Application of the 1940 Act}

Determining whether the pooled fund itself or the charitable institution that maintains the fund is the issuer of the life income interests received by donors is crucial for the application of the Investment Company Act of 1940 as well as the 1933 Act. Section 3(a)(1) of the 1940 Act provides that an investment company is any issuer that "is ... engaged primarily ... in the business of investing, reinvesting, or trading in securities." If If the donee institution is deemed the issuer for purposes of the 1933 Act, it will not be subject to registration as an investment conipany under the 1940 Act, since it is primarily engaged in a business other than that of investing in securities. If the double entity theory is applied, however, the fund itself, rather than the donee institution that inaintains the fund or the bank that serves as the trustee of the fund, will be deenied the "issuer" of the security under both the 1933 and 1940 Acts. ${ }^{77}$ Since the sole business of the

73. 15 U.S.C. $\$ 77 c(a)(2)(1970)$.

74. The exemption was adopted as an amendment to section 3(a)(2) of the 1933 Act by the Investment Company Amendments Act of 1970, Pub. L. No. 91547, $\$ 27(a), 84$ Stat. 1413 (1970). The House Report on that Act discusses the exemption as follows:

The proposed amendment [to Section 3(a)(2) of the 1933 Act] would exempt from the registration provisions of the [1933] Act interests and participations in the traditional common trust funds maintained by banks as investment vehicles for the assets held by the bank in a bona fide fiduciary capacity. This is identical to the exemption for a "common trust fund or similar fund" in Section 3(c) (3) of the Investment Company Act. This exemption is limited to interests or participations in common trust funds maintained by a bank for the collective investment of assets held by it in a bona fide fiduciary capacity and incident to a bank's traditional trust department activities; it would not exempt interests or participations in bank funds maintained as vehicles for direct investment by individual members of the public.

H.R. REP. No. 1382, 91st Cong., 2d Sess. 43 (1970) (emphasis added).

75. See text accompanying notes 76-91 infra.

76. 15 U.S.C. $\$ 80 a-3(a)(1)(1970)$.

77. See text accompanying notes 58-60 supra. 
pooled income fund trust is that of investing in a portfolio of securities, the fund would probably be deemed an investment company within the meaning of section 3(a)(1) of the 1940 Act. $^{78}$ Because the fund would not be issuing a "redeemable security" within the meaning of the Act, it would be classified as a "closed-end company" under section 5(a)(2) of the Act. ${ }^{79}$

Section 7 of the 1940 Act provides that no investment company, depositor, or trustee of or underwriter for any investment company shall offer, sell, or deliver after sale, any security issued by that investment company unless the investment company is registered under the Act. ${ }^{80}$ The 1940 Act's definition of "underwriter" is identical to that in the 1933 Act. $^{81}$ Thus, if the double entity theory is applied, to the extent the donee institution solicits donors, it will be deemed an underwriter under the 1940 Act as well as under the 1933 Act. The donee institution will therefore violate section 7 of the 1940 Act unless the pooled fund is registered as an investment company, or unless the fund is exempt from the requirements of registration. Although the Act provides several possible exemptions, none is available if the double entity theory is applied.

\section{Possible Exemptions When the Donee Institution is Trustee}

If the donee imstitution, rather than a bank, acts as trustee for the pooled income fund trust, the only exemptions available under the 1940 Act are found in sections 3(c)(1) and 3(c)(10). Section 3(c)(1) excludes from the definition of investment company: "Any issuer whose outstanding securities (other than short-term paper) are beneficially owned by not more than one hundred persons and which is not making and does not presently propose to make a public offering of its securities." 82 This exemption is limited to issuers that qualify for the nonpublic offering exemption contained in section $4(2)$ of the 1933 Act. Since the typical pooled income fund trust will be unable to qualify for exemption under section 4(2) of the 1933 Act, ${ }^{83}$ it can not qualify under section 3(c)(1) of the 1940 Act. The other possible exemption, section 3 (c) (10),,$^{84}$ is in substance identical to the exemption for certain nonprofit organizations contained in section 3(a)(4)

78. See Prudential Ins. Co. v. SEC, 326 F.2d 383 (3d Cir.), cert. denied, 377 U.S. 953 (1964).

79. 15 U.S.C. $\$ 80 a-5(a)(2)(1970)$.

80. 15 U.S.C. \& 80a-7 (1970).

81. Compare 15 U.S.C. $\S 80 \mathrm{a}-2(40)$ (1970) (the 1940 Act), with 15 U.S.C. $\S 77 \mathrm{~b}(11)$ (1970) (the 1933 Act).

82. 15 U.S.C. $\$ 80 \mathrm{a}-3$ (c)(1) (1970) (emphasis added).

83. See text accompanying notes 68-70 supra.

84. 15 U.S.C. $\$ 80 a-3(c)(10)(1970)$. 
of the 1933 Act. ${ }^{85}$ As under the 1933 Act, the retention of a life income interest by donors will disqualify a pooled income fund trust from this exemption under the 1940 Act. $^{86}$

\section{Possible Exemptions When a Bank is Trustee}

Section 3(c)(3) of the 1940 Act provides a special exemption, identical to that contained in section 3(a)(2) of the 1933 Act, for "any common trust fund or similar fund maintained by a bank exclusively for the collective investment and reinvestment of monies contributed thereto by the bank in its capacity as a trustee, executor, administrator or guardian." 87

The SEC has never extended the section 3(c)(3) exemption beyond the traditional, individually negotiated common trust fund arrangements maintained by a bank for trust administration purposes. Rather, the Commission has taken the position that a bank commingled investment fund, whether in the form of a trust or in the form of a managing agency account, is engaged in the business of a conventional investment conipany, and nust register under the 1933 and 1940 Acts if it is merchandised as an investment medium to the general public. ${ }^{88}$ In hight of this position, the First National City Bank registered the conimingled nuanaging agency account that it offered as an investment vehicle in 1965 as an investment conipany under the 1940 Act. ${ }^{80}$ The SEC asserted the same theory in its challenge to First National's Special Investment Advisory Service (SIAS), which was established after the Suprene Court held the managing agency account to be a violation of the Glass-Steagall Act. ${ }^{00}$ The Commission's complaint alleged that the separate investor accounts making up SIAS were one investment company because SIAS was merchandised to the general public as a pooled investment vehicle. ${ }^{01}$

85. Compare 15 U.S.C. $\$ 80 \mathrm{a}-3(\mathrm{c})(10)$ (1970) (the 1940 Act), with 15 U.S.C. $\$ 77 \mathrm{c}(\mathrm{a})(4)$ (1970) (the $1933 \mathrm{Act}$ ).

86. See text accompanying notes 63-67 supra.

87. 15 U.S.C. $\$ 80 a-3(c)(3)$ (1970). Only one-third of colleges and universities manage their entire endowment internally. The externally managed funds seem to achieve superior results, and in many cases the external manager is a bank. W. CARY \& C. BRight, The Developing LaW of Endowment Funds: "The LaW and the LORE" Revisited: A Report to the Ford Foundation 23-25 \& n.* (1974).

88. Collective Investment Funds: Hearings on S.2704 Before the Subcommittee on Securities of the Senate Committee on Banking and Currency, 89th Cong., 2d Sess. 136-37 (1966) (testimony of Chairman Cohen); see also public letter of Chairman Cary, reported by Professor Loss, in. 4 Loss, supra note 12, at 2541.

89. First National City Bank, Investment Company Act Release No. 4538 (March 9, 1966).

90. For a fuller description of these events, see text accompanying notes 20-26 supra.

91. [1970] SEc. REg. \& L. ReP. (BNA), No. 37 at A.4 (Feb. 11, 1970). 
A pooled income fund trust for which a bank serves as a trustee is more analogous to these nonexeinpt bank trust funds than to the exempt bank common trust fund. The pooled income fund trust is an investunent vehicle that pools separate life incoine trusts on behalf of individual donors; the terms of participation in the pooled fund are standardized rather than individually negotiated with each donor; and interests in such funds are inerchandised, by the donee institution, by means of soliciting the general public for contributions.

\section{Special Problems of Bank Trustees}

The experience of National City Bank with its managing agency account is instructive in the context of pooled income fund trusts in connection with the availability of the bank common trust fund exemption to the fund and the donee institution. Futhernore, it is also inportant in relation to possible violations of the Glass-Steagall Act and the 1933 and 1940 Acts by the bank that serves as trustee of a pooled fund. If the double entity theory is used to make a pooled income fund trust held by a trustee bank a separate issuer, a donee institution that publicly offers interests in the pooled incoine fund trust will be deemed an underwriter of the interests being issued by the separate trust. ${ }^{92} \mathrm{~A}$ bank trustee for such a trust likewise might fall within the definition of the term "underwriter" under the securities laws if the bank "has a direct or indirect participation in any such undertaking"93 by the donee institution, as for example, if the bank personnel initiate discussions regarding the pooled fund, or provide written inaterials regarding the fund to bank customers or other persons. Since the Glass-Steagall Act prohibits a bank from "underwriting" securities, ${ }^{94}$ considerimg a bank an "underwriter" under the securities laws might also cause the bank to be engaged in an activity prohibited by the Glass-Steagall Act.

The possibility of applying the Glass-Steagall Act to banks serving as trustees for pooled funds is illustrated by Investment Company Institute v. Camp. ${ }^{95}$ In Camp, an association of investment coinpanies operating open-end inutual funds ${ }^{96}$ attacked the Coinptroller's author-

92. See text following note 62 supra.

93. 1933 Act $\$ 2(11), 15$ U.S.C. $\$ 77 b(11)$ (1970).

94. Section 16 of the Act, 12 U.S.C. $\& 24$ (1970), prohibits a national bank from underwriting any issue of securities and from purchasing any such securities for its own account. Section 21, 12 U.S.C. $\$ 378(1970)$, prohibits a national bank from engaging in the business of issuing, underwriting, selling, or distributing stocks or securities.

95. 401 U.S. 617 (1971).

96. Mutual funds generally are open-end investment companies engaged in the business of continuously issuing and offering for sale redeemable securities that represent an undivided interest in the fund's assets. The open-end mutual fund continuousiy 
ization of banks to establish and operate collective investment funds. The Comptroller had authorized First National City Bank to offer its customers the opportunity to invest in a stock fund created and maintained by the bank. ${ }^{07}$ The Court described the fund ${ }^{08}$ and concluded: "The differences between the investment fund that the Comptroller has authorized and a conventional open-end mutual fund are subtle at best, and it is undisputed that this bank investment fund finds itself in direct competition with the mutual fund industry." that Congress took the "drastic step" under the Glass-Steagall Act of prohibiting commercial banks from entering the investment banking business directly or indirectly because the earlier lack of such a prohibition had aggravated the stock market decline of the 1930's. ${ }^{100}$ The Court focused on the bank's role as promoter of the fund and the possible conflicts between that role and commercial banks' more traditional functions. ${ }^{101}$

issues and offers new securities. See generally Investment Co. Inst. v. Camp, 274 F. Supp. 624, 629-631 (D.D.C. 1967), rev'd per curiam sub nom. N.A.S.D., Inc. v. SEC, 420 F.2d 83 (D.C. Cir. 1969), rev'd sub nom. Investment Co. Inst. v. Camp, 401 U.S. 617 (1971). See also 15 U.S.C. $\$ \$ 80 \mathrm{a}-2(\mathrm{a})(21), 80 \mathrm{a}-3$ (a)(1), 80a-5(a)(1), $80 \mathrm{a}-4(2)$ (1970).

97. When the Federal Reserve Board had jurisdiction over most of the trust activities of national banks, it consistently ruled that a bank could not use a common trust fund as an investment trust attracting money seeking investment alone and to embark upon what would be in effect the sale of participations in a common trust fund to the public as investments. E.g., 26 Fed. Res. Bull. 393 (1940).

98. 401 U.S. at 622-23:

Under the plan the bank customer tenders between $\$ 10,000$ and $\$ 500,000$ to the bank, together with an authorization inaking the bank the customer's managing agent. The customer's investment is added to the fund, and a written evidence of participation is issued which expresses in "units of participation" the customer's proportionate interest in fund assets. Units of participation are freely redeemable, and transferable to anyone who has executed a managing agency agreement with the bank. The fund is registered as an investment company under the Investinent Company Act of 1940 . The bank is the underwriter of the fund's units of participation within the meaning of that Act. The fund has filed a registration statement pursuant to the Securities Act of 1933. The fund is supervised by a five-member committee elected annually by the participants pursuant to the Investment Company Act of 1940. The Securities and Exchange Commission has exempted the fund from the Investment Company Act to the extent that a majority of this committee may be affiliated with the bank. . . .

99. Id. at 625 .

100. Id. at 629.

101. [Entering the investment banking business] places new promotional and other pressures on the bank which in turn create new temptations. . . . [T]he bank's salesman's interest inight impair its ability to function as an impartial source of credit.

... [T]he promotional needs of investment banking might lead commercial banks to lend their reputation for prudence and restraint to the enterprise of selling particular stocks and . . . this could not be done without that reputation being undercut .... [If] commercial banks were subject to the promotional demands of investment banking, they might be tempted to make loans to customers with the expectation that the loan would facilitate the 
In the situation of pooled income fund trusts, if the bank becomes too closely involved in assisting the donee institution to solicit donations, its role becomes similar to that found to be prohibited in Camp. To the extent that bank activity promotes a pooled trust, the bank begins to compete directly with traditional investment banking activities. The bank is no longer acting "in a bona fide fiduciary capacity and incident to a bank's traditional trust department activities."102 Rather, the bank is selling "participations in bank funds inaintained as vehicles for direct investment by individual members of the public."103 Thus, to the extent that a bank solicits contributions or aids the donee in soliciting contributions to a pooled fund for which it is trustee, it could be found to be in violation of the Glass-Steagall Act.

The same considerations which underlay the Camp decision also support finding a bank trustee who solicits donations for or who otherwise promotes a pooled fund to be an underwriter under the 1933 and 1940 Acts. In these circumstances, the bank presumably could not qualify for the bank common trust fund exemption in section 3(c)(3) of the 1940 Act nor the complementary exemption in section 3(a)(2) of the 1933 Act, since the bank would be promoting the fund as an investment device to the general public. ${ }^{104}$ Indeed, the SEC staff has suggested that a bank common trust fund might lose its exemptions under the 1933 and 1940 Acts where the bank itself simply creates common trust funds exclusively as a vehicle for investment of contributions made in a number of separate pooled income fund trusts. ${ }^{105}$ The theory supporting this suggestion seeins to be that a bank's creation of such an "exclusive" common trust fund is outside the bank's "traditional trust department activities" for purposes of the securities laws. If the bank solicited donee mstitutions to reinvest property contributed to their pooled income fund trusts in such a common trust fund, such activity might likewise raise a question under the Glass-Steagall Act.

In summary, if the double entity theory of an issuer is applied to pooled imcoine fund trusts, the registration requirements of the 1933

purchase of stocks . . . .

... [there is a] plain conflict between the promotional interest of the investment banker and the obligation of the commercial banker to render disinterested investment advice."

Id. at 630-33 (emphasis added) (footnotes omitted).

102. H.R. REP. No. 1382, 91st Cong., 2d Sess. 43 (1970) (describing the exemption for bank common trust funds from the securities laws). See note 74 supra.

103. Id.

104. See text accompanying notes 71-75, 87-91 supra.

105. "No Action" Letter to Allentown College of St. Francis de Sales (available July 9, 1976) and "No Action" Letter to Citizens Bank \& Trust Co. and American Bureau Research Foundation (available Sept. 2, 1973) (copies on file with the California Law Review). 
and 1940 Acts will be applicable. None of the statutory exemptions will be generally available.

\section{III}

\section{The SEC Position on Pooled Income Fund Trusts}

Although application of the double entity theory would render the registration requirements of the 1933 and 1940 Acts applicable to pooled income fund trusts, the SEC staff has determined not to insist upon registration of such funds. In November 1972, the American Council on Education requested that the SEC staff recominend "no action" 106 to the Cominission for pooled incoine trusts of eligible colleges. In response, the staff issued a "No Action" letter. ${ }^{107}$

106. A "no action" letter is informal, interpretative legal advice by the SEC staff in which it indicates that, on the basis of certain facts stated in a letter or other communication, "the staff would not recommend that the Coinmission take any cnforcement action, together with any written response thereto." 17 C.F.R. $\S 200.81$ (a) (1977). The procedure to receive no action and interpretative letters is outlined in Securities Act Release No. 5127 (Jan. 22, 1971).

A "no action" letter does not operate to bind third parties. Cf. Securities Act Release No. 4552 (Nov. 6, 1962). The SEC has also argued that a "no action" letter does not even bar the Commission staff from later instituting an enforcement action against the recipient of a no action letter. Brief of SEC, Abbett, Sommer and Co. v. SEC, (D.C. Cir.), cert. denied, 401 U.S. 974 (1971), cited in 3 H. BLOOMENTHAL, Securrties aNd Federal Corporate LaW $\$ 1.11$ at 1-40 (1975); Hacker \& Rotunda, Sponsors of Real Estate Partnerships as Brokers and Investment Advisers, 23 U.C.L.A. L. REv. 322, 328-29 n.34 (1975).

107. "No Action" Letter of Dec. 14, 1972 to American Council on Education, [1972-73 Transfer Binder] FED. SEC. L. REP. (CCH) I 79,179:

Based on the facts and representations in this letter, we will not recommend that the Commission take any action if eligible colleges (or other eligible charities) cstablish and maintain pooled income fund trusts which qualify as recipients of tax-deductible contributions under Section $642(c)(5)$ of the Internal Revenue Code without registration (1) under the Investment Coinpany Act of 1940 of such pooled trust, or of the college which inaintains such trust, or of any trustee of such pooled trust, including any bank, (2) under the Securities Act of 1933 of any interests in such pooled trust, (3) under the Securities Exchange Act of 1934 of any persons soliciting gifts by means of such pooled trust. Our position is conditioned on each prospective donor receiving written disclosures which fully and fairly describe the operation of the particular pooled trust. In this connection we would like to make it clear that $m$ our view the antifraud provisions of the federal securities laws are applicable to sales of interests in these trusts.

While we do not necessarily agree with your legal interpretation of the exemption provided by Section 3(a) (4) of the Securities Act of 1933 and the exception provided by Section $3(\mathrm{c})(10)$ of the Investment Company Act of 1940, or your view that no "sale" for "value" occurs, the foregoing is based on recognition of the fact that the primary purpose of persons who transfer property to pooled income trusts is to make a gift to the charity of their choice. That, together with applicable Internal Revenue Code and Treasury Department restrictions and regulations, make registration under the federal securities laws appear unnecessary in these circumstances.

See also "No Action" Letter of May 25, 1973 to Jewish Community Federation; Jewish Welfare Funds, [1973 Transfer Binder] FEd. SEc. L. REp. (CCH) T 79,419. 
Two aspects of the letter are noteworthy. First, the staff specifically refused to concur in the legal interpretation that the section 3(a)(4) exemption under the 1933 Act and the section 3(c)(10) exemption under the 1940 Act are available for pooled income fund trusts. By refusing to concede that the exemptions for nonprofit institutions were available the staff, in effect, preserved its double entity interpretation in the context of pooled incoine fund trusts as well as of other analogous educational and charitable pooled investment funds. Second, the staff concluded that, regardless of the legal grounds for registration under the federal securities laws, such registration would be unnecessary in the circunstances because of public policy considerations. Two separate types of public policy considerations support the staff's actions. Policies concerning the need for registration and those concerning the burden of registration will be discussed in some detail.

\section{A. The Need for Registration}

One important determination that appears to underlie the SEC's "no action" position is that qualified pooled trusts do not typically lend themselves to the types of abuses against which the registration provisions of the securities laws are directed. First, the nature of the "issuer" makes such abuses less likely. Under the Code pooled trusts may be organized and maintained only by public charities of the type which themselves qualify for the charitable organization exemptions from registration under the securities laws. ${ }^{108}$ Typically no private promoter or orgamizer receives any pecuniary profits from the organization or promotion of the pooled trust, and no commissions are paid to salesmen or others in connection with the solicitation of gifts to pooled trusts. Hence there is not the same danger of overreaching or misrepresentations by self-interested promoters or salesmen.

Moreover, the nature of the "investors" in such funds also suggests that registration is not needed. Upon 1nakmg a contribution to a pooled trust, a donor is entitled to a charitable deduction ineasured by the value of the remainder interest in the property transferred to the trust. $^{108}$ Neither the donor nor his income beneficiaries may thereafter recover any portion of that property or of its appreciated value. Thus, the primary purpose of persons who transfer property to qualified pooled trusts seems to be that of making a gift to the charity of their choice. Making an investment with a view to anticipated return is only a secondary purpose. In most instances such persons will have some close connection with, or other direct interest in, the public charity in-

108. Treas. Reg. $\S 1.642(\mathrm{c})-5$ (1971).

109. I.R.C. $\S \S 170(f)(2)(A), 642(c)$. 
volved. In addition, under the Commission's "no action" position the public charity must provide prospective donors with a booklet or similar document which fully and fairly describes the operation of the particular pooled trust. Thus the donor's need for information should be fully satisfied without registration. Finally, a donor's decision to make a gift in trust is often made after consultation with tax and other counsel because of the special tax and estate planning considerations that are norinally involved in the decision to inake a substantial charitable gift. Such donors may ordinarily be regarded as fully able to look after their own imterests in arranging with their chosen public charities the inanner by which they make their charitable gifts.

The extensive disclosures required in the prospectus, annual and other reports of a registered investment coinpany are not really necessary in the context of a qualified pooled trust because of the nature of the investment. Donors or income beneficiaries are called upon to make only a very linnited and initial investment decision. There is no great need for extensive disclosures concerning a pooled trust's investment policies or the background and experience of its investment managers, or any proposed changes in such policies or managers, because, under the Code, donors and income beneficiaries have no right to vote to approve or disapprove a pooled trust's investment policies or the selection of persons to manage the trust. The Regulations require that the charitable institution, as opposed to the incoine beneficiaries, maintain, or control, the trust. ${ }^{110}$ In addition, they provide that no donor or beneficiary inay serve as trustee or directly or indirectly have general responsibilities with respect to the trust that would ordinarily be exercised by a trustee. ${ }^{111}$ Thus, all such decisions are vested exclusively in the donee public charity. Nor do donors and income beneficiaries need such information to determine whether they should stay in or get out of the pooled trust since, under the Code, the remainder interest granted to the charity inust be irrevocable. ${ }^{112}$ They may not opt out of the trust by redeeming any part of their contributed principal, even if they disagree with the decisions of the donee public charity that maintaims the trust.

Further, there is little danger that, in the absence of the full range of disclosures contained in a typical investment company prospectus, a public charity or its agents would exaggerate the rate of return that donors inight be expected to receive. Under the Code, a high rate of return earned by a pooled trust reduces the amount of charitable de-

110. Treas. Reg. $\$ 1.642(c)-5(b)(5)(1971)$.

111. Id. \& $1.642(\mathrm{c})-5(\mathrm{~b})(6)$.

112. Id. $\& 1.642(\mathrm{c})-5(\mathrm{~b})(1)$. 
duction allowed to a donor upon the transfer of property to the trust. ${ }^{113}$ Hence, it is reasonable to assume that high performance is often not a determining motivation behind a donor's decision to make a gift to a qualified pooled trust.

The Code restricts pooled trusts in other ways that diminish the need for its regulation under the securities laws. The Regulations specifically provide the method by which income must be allocated to income beneficiaries. ${ }^{114}$ Moreover, pooled trusts are subject to certain of the provisions in the private foundation section of the Code: the restrictions against self-dealing, the restrictions against making taxable expenditures and, possibly, the restrictions against excess busmess holdings and investments that would jeopardize the institution's charitable purpose. ${ }^{115}$ These provisions were designed to deal with the abuses that might arise in connection with the formation and operation of pooled trusts. Any abuses that might arise despite these provisions of the

113. The regulations provide tables, Treas. Reg. $\$ 1.642(c)-6(d)(3)$ (1971), whereby the value of a gift in a pooled trust can be determined for purposes of calculating the applicable charitable deduction. This value depends on the life expectancy of the income beneficiary and the applicable discount factor. The discount factor is a percentage equal to the highest rate of return of the pooled trust for the three years immediately preceding the year in which the transfer of property to the trust is made. If the trust has not been in existence for at least three years, the factor of six percent must be used, unless a different rate is prescribed by the Internal Revenue Service. Consequently, the higher the rate of return earned by a pooled trust, the lower the amount of the charitable deduction allowed to a donor for a specific gift, and vice versa. For this reason, it is essential that, as described in the text accompanying notes 110-111 supra, the charitable donee, or its designated trustee, control the pooled trust, rather than the donors and income beneficiaries. Otherwise, it might be possible for donors to contribute to a trust with a relatively low discount factor, and thereby obtain a relatively high charitable deduction, and then participate in the investment decision making process, so that the income rate increased substantially, to the detriment of the remainder interest.

114. Income beneficiaries must receive a proportionate share of the annual income earned by the trust based on the units of participation of the trust assigned to the income interest upon the transfer of property to the trust. The number of units of participation to which one is entitled is determined by dividing the fair market value of the transferred property by the fair market value of one unit of participation in the trust at the time of transfer. The fair market value of one unit of participation is determined by dividing the fair market value of all property of the trust, as determined on the "determination date" innnediately preceding the date of the transfer of the property in question, by the number of units then in the trust. Where property is transferred between determination dates, treasury regnlations require that there be "appropriate adjustunents" to the number of units allocated as a result of the transfer of property on the "next succeeding" determination date. The regulations provide that such adjustments may be made "by any reasonable method," including the use of a method whereby the fair market value of the property $\mathrm{m}$ the trust at the time of transfer is deeined to be the average of the fair market values of the property in the trust on the determination dates immediately preceding and succeeding the date of transfer. Treas. Reg. $\$ 1.642(c)-5(c)(2)$ (1971). On determination dates, see notes 130-131 infra and accompanying text.

115. I.R.C. $\$ \S 4947,4941,4945,4943 \& 4944$, respectively. 
Code and the regulatory authority vested in the Treasury can be handled under the antifraud provisions of the securities laws, which the SEC's "no action" letter states shall continue to be applicable to the sale of interest in these trusts.

Finally, there should be no speculative abuses resulting from the trading in pooled trust interests. These interests are nonredeemable, ${ }^{116}$ and, since the governing instruinent must specify the named income beneficiaries, ${ }^{117}$ interests cannot be publicly traded or otherwise tranferred for profit.

Both the SEC letter and the foregoing analysis suggest certain limits to the Commission's "no action" position. The Commission's letter was based upon the facts and representations contained in the letter of the American Council on Education. The Council's letter represented that the pooled income fund trusts in question were not organized or promoted by any profit-motivated promoter or sponsor. Under the previous analysis of the policy considerations underlying the SEC position, a serious question would arise under the registration provisions of the securities laws if a private, profit-1notivated sponsor, such as an investinent adviser or a bank, actively solicited and assisted one or more donee institutions in organizing such a fund, for which the sponsor would then serve as investment adviser or trustee. Although the Commission's "no action" position encompasses "any trustee of such pooled trust, including any bank," the letter of the Council makes clear that any such bank would be acting in a manner incidental to its traditional trust department activities at the behest of a donee institution, and would not be actively sohciting donee institutions as prospective trust department customers. ${ }^{118}$

When the bank is the promoter, it is not merely performing a traditional trust department service for its customer, a fact crucial to

116. The interests are nonredeemable because the remainder granted the trust must be irrevocable. Treas. Reg. $\$ 1.642$ (c)-5(b)(1) (1971).

117. See note 42 supra.

118. The "No Action" letter, which incorporates by reference the letter of the American Council on Education, thereby explicitly excludes such active promoting by a bank. That letter stipulates that: "Any fees received by such a trustee or investment manager [e.g., a bank], would be merely incidental to a college's establishment and maintenance of the pooled trust and would provide no opportunities for personal profits. ..." Letter from American Council on Education to the Commission staff (Nov. 3,1972 ). The "No Action" letter is explicitly based on the facts and representations in the letter by the party seeking no action status. See note 107 supra.

The requirement of the Internal Revenue Code that the pooled income fund trust be established and maintained only by a bona fide public charity for the exclusive purpose of raising funds for its charitable purposes does not affect the possibility that the bank, as promoter, will have a profit motive, i.e., the fees it receives for managing the fund. 
the finding in Camp that the bank was "underwriting" securities. ${ }^{119}$ Under these facts a court might find structural similarities between the pooled trust and the bank managing agency account prohibited in Camp. The beneficiary of the trust (the income recipient of the life estate) and the settlor are often the same. Also, to the extent the bank actively encourages a donee institution to organize and maintain the fund, the bank is not acting "in a bona fide fiduciary capacity and incident to a bank's traditional trust department activities." ${ }^{\text {"20 }}$ Rather, the bank, in effect, is actively selling "participations in bank funds inaintained as vehicles for direct investment by individual members of the public," ${ }^{121}$ using the donee institution as its agent.

Under this analysis, when the bank acts as an active promoter, the SEC could well invoke the double entity theory and consider the bank an underwriter of securities issued by its separate trust account, despite the "no action" position taken with respect to the letter of the American Council. The bank inight likewise be deemed to be engaged in prohibited underwriting activities for purposes of the Glass-Steagall Act. ${ }^{122}$

\section{B. The Burden of Registration-Inconsistency Between the Code and the Securities Laws}

A further consideration which appears to underlie the SEC's "no action" position is that compliance by pooled income fund trusts with the full panoply of regulations under the 1933 and 1940 Acts would be inconsistent with both the spirit and the specific provisions of section 642(c)(5) of the Code.

The purpose of Congress in adopting section 642(c)(5) of the Code was to encourage gifts to educational and other charitable organizations. The section thus inakes it possible for donors to receive an immediate tax deduction for gifts to such charities and still retain a continuing source of income from the property donated for the lifetimes of designated beneficiaries. Donors also may receive benefits under section 642 (c)(5) by the elimination of capital gains on appreciated property that is transferred to a qualified pooled trust. By providing these tax incentives to donors for gifts to eligible public charities, Congress recognized the pressing need of private educational and other charitable organizations to find a new source of funds if they are to continue to meet the costs involved in performing their important public

119. See notes 95-103 supra and accompanying text.

120. H.R. Rep. No. 1382, 91st Cong., 2d Sess. 43 (1970) (describing the exemption from the securities laws for bank common trust funds). See note 74 supra.

121. Id.

122. See text accompanying notes 95-103 supra, 
services. In contrast, the registration, periodic reporting and recordkeeping requirements of the 1933 and 1940 Acts would make the solicitation of donations by means of pooled trusts prohibitively expensive for most eligible public charities, ${ }^{123}$ contrary to Congress' intent to encourage such gifts.

In addition, compliance with certain provisions of the 1940 Act is inconsistent with specific regulations under section $642(\mathrm{c})(5)$ of the Code. Sections 10,13(a), 15, 16,18(i), and 32(a) and (b) of the $1940 \mathrm{Act}^{124}$ provide for security-holder participation in the management of investment companies. The Code's requirement that the power to appoint and remove trustees of a qualified pooled trust must be maintained by the donee charity, and not by donors or income beneficiaries, ${ }^{125}$ prevents such a trust from complying with section 16 of the 1940 Act, which requires that "directors," who are defined to include trustees, of a pooled trust inust be elected by the income beneficiaries. Likewise, the Code's requirement that no donor or income beneficiary, directly or indirectly, have responsibilities of the kind ordinarily exercised by a trustee ${ }^{126}$ prevents a pooled trust from complying with sections 13,15 , and 32 . These sections require income beneficiaries to approve any changes in a pooled trust's basic investment policies and certain other fundamental business activities. The Code and the 1940 Act are thus inconsistent, since such determinations are of the kind ordinarily inade by a trustee. In light of the foregoing, and since pooled trusts ordinarily do not even have boards of directors, qualified pooled trusts also are unable to comply with sections 10 and 18 (i), which require that a certain percentage of the pooled fund's "directors" be independent of the donee institution and that income beneficiaries be given voting rights.

Neither can pooled trusts coinply with section 23(a) of the 1940 Act, ${ }^{127}$ if such trusts are to operate in the manner contemplated under the Code. In adopting section $642(\mathrm{c})(5)$ of the Code, Congress intended to encourage gifts to eligible charities, without limiting the form

123. A decade and a half ago it was estimated that legal fees alone in a first public offering would cost up to $\$ 30,000$. Wheat \& Blackstone, Guideposts for a First Public Offering, 15 Bus. LAw. 539, 551 (1960). Legal fees now can be expected to run to $\$ 50,000$ or more. In addition there are accounting fees, printing costs, blue sky filing fees, and other expenses. There is also a filing fee with the SEC. The expenses of any pooled trust registration will be increased because there will have to be a continual offering. It is difficult to underestimate the costs of registration.

124. 15 U.S.C. $\S \S 80 \mathrm{a}-10,-13(\mathrm{a}),-15,-16,-18(\mathrm{i}),-32(\mathrm{a})$, (b) (1970 \& Supp. V 1975).

125. See text accompanying note 110 supra.

126. See text accompanying note 111 supra.

127. 15 U.S.C. $\S 80 a-23$ (a) (1970). 
of such gifts to cash or securities. ${ }^{128}$ Section 23(a), however, would preclude pooled trusts from accepting gifts of property other than cash or securities.

Another conflict arises between the Code and section 23(b) of the 1940 Act. $^{129}$ The Code provides that pooled trust assets must be valued as of specified "determination dates",;30 units for determining the allocation of income to donated property are then based upon the valuation of a pooled trust's assets on the "determination date" next following a transfer of property to the pooled trust, when the transfer occurs between "determination dates." 131 This provision for valuation of units on specified "determination dates" appears to be inconsistent with section 23(b), which requires issuers registered under the 1940 Act to value their units at "current" net asset value.

Section 17 of the $1940 \mathrm{Act}^{132}$ presents further difficulties. If applied to a pooled trust, section 17 would prohibit, among other things, the joint, or joint and several, participation im any transactions by a pooled trust and the charitable organization that mamtains the trust. Thus, the section would effectively prevent the purchase or sale of securities or other property by an educational mstitution for its general endowment fund concurrently with the purchase or sale of such securities or property on behalf of the pooled trust. It would also apparently prohibit a donor from dividing a gift of property between the institution's general endowment fund and its pooled trust. Further, section 17 may prohibit a pooled trust from commingling properties held in trust with the institution's other general endowment properties for purposes of common investment, even though such commingling of properties is specifically contemplated under the Code so long as sufficient accounting is maintained to identify properties subject to life income trusts. ${ }^{133}$ Application of section 17 not only raises numerous complications for charitable organizations, but also would be superfluous simce the Code contains specific provisions designed to regulate self-dealing with respect to pooled trusts. ${ }^{134}$

Thus, both because the protection of the securities laws is not needed by donors who "mvest" in pooled income fund trusts and be-

128. See Treas. Reg. $\$ 1.642(c)-5(b)(4)$ (1971).

129. 15 U.S.C. \& 80a-23(b) (1970).

130. Under the regulations, there must be at least four determination dates within a taxable year and the period between any two consecutive determination dates within a taxable year may not be greater than three calendar months. Treas. Reg. $\$ 1.642$ (c) $-5(a)(5)$ (vi) (1971).

131. Id. $\$ 1.642(\mathrm{c})-5(\mathrm{c})(2)$.

132. 15 U.S.C. $\& 80 \mathrm{a}-17$ (1970).

133. Treas. Reg. \& 1.642 (c)-5(b)(3) (1971).

134. See note 115 supra and accompanying text. 
cause the incoinpatibility of the securities laws and the Code places an impossible burden on such trusts, their exemption from the 1933 and 1940 Acts is clearly necessary.

\section{IV}

\section{Pooled Pension Plans of Chartable and EDUCATIONAL INSTITUTIONS}

The foregoing analysis of the "no action" position taken by the SEC staff with respect to charitable pooled income fund trusts provides a useful point of reference in analyzing application of the securities laws to another type of pooled fund created by educational and charitable institutions as a vehicle for private investments. Many educational institutions, churches, and fraternal organizations pool contributions made by themselves and by their employees or representatives for common investment in their employee retirement plans. ${ }^{135}$ Such pooled funds take a variety of forms. Some institutions have created self-adıninistered, separate funds providing for retirement benefits to their employees. ${ }^{136}$ Other institutions invest their contributions and their employees' contributions to such retirement plans in the institution's general endowinent funds. Many state-supported institutions participate in a general pooled retirement plan for all state employees created by the state legislature. ${ }^{137}$ Religious institutions and churchrelated schools and charities may all participate in a single denominational pooled retirement fund for all clerical and lay workers. ${ }^{138}$

Many of these pooled retirement funds, regardless of their form of organization, provide employees with a variable annuity in which the retiree's return is dependent upon fluctuations in the market price of the portfolio of securities held by the pooled fund. ${ }^{139}$ The interests in such variable annuities are clearly "securities." Where employees have a choice whether to participate in and make contributions to such retirenent funds, the employees have given "value" in return for the variable annuity interest. Such pooled retirement funds, therefore, involve the "sale" of "securities" within the meaning of the securities laws.

135. E.g., the University of Rochester, University of California, and Massachusetts Institute of Technology.

136. E.g., the Massachusetts Institute of Technology has a self-administered plan for its faculty and staff; the University of Rochester has a self-administered plan for its nonacademic employees.

137. E.g., the University of Wisconsin and Rutgers University cover faculty and staff by participating in the state teacher and public employees retirement system created by the state legislatures. Plan.

138. E.g., the Lutheran Church in America's Ministerial Pension and Death Benefit

139. E.g., Massachusetts Institute of Technology, University of Rochester, University of California, University of Wisconsin, and Rutgers University. 
As in the case of pooled incoine fund trusts, the double entity theory may disqualify such pooled funds, created by charitable institutions as a vehicle for private investment, from the charitable organization exemptions under the securities laws. This theory would treat the pooled retirement fund, which is not itself an exempt entity, as the issuer of the variable annuity interests; the exempt charitable or educational institution would then be viewed as the "investment adviser," "underwriter," or "controlling person" of the separate fund. The double entity theory could be applied regardless of whether the particular pooled fund were organized as a separate fund or coinmingled with the institution's general endowment fund or with the funds of other participating institutions.

The securities laws provide no exemption for such pooled retirement plans if the double entity theory is applied to deny them the charitable organization's general exemption. ${ }^{140}$ Section $3(a)(2)$ of $1933 \mathrm{Act}^{141}$ and section 3(c)(11) of the $1940 \mathrm{Act}^{142}$ specifically exempt from the registration requirements of those Acts employee retirement plans that qualify under section 401 of the Internal Revenue Code. Retirement plans administered by educational and charitable institutions typically are qualified under section 403(b) of the Code, which grants tax benefits for annuities of employees of nonprofit educational and charitable organizations equivalent to the benefits provided to qualified industrial pension plans. The securities laws, however, provide no exemption for educational or charitable pension plans qualified under section 403 (b) comparable to the exemptions provided for industrial pension plans qualified under section 401.

Even where no statutory exeinptions are clearly available, the staff may nevertheless take a "no action" position with respect to registration for public policy reasons, such as the position adopted with respect to charitable pooled incoine fund trusts. Three public pohicy reasons behind the staff's "no action" position with respect to pooled income fund trusts have been identified. First, the primary motivation of a participant in inaking a contribution to such a trust is to give a charitable donation to the donee institution which operates the trust. ${ }^{143}$ Second, such a trust tends not to be subject to the types of abuses against which the securities laws were directed since the trust is not organized or promoted for profit, nor are the participation interests therein sold by any profit-motivated sponsors or salespersons. ${ }^{144}$ Third, registration of

140. See text accompanying notes 63-67 and 84-86 supra.

141. 15 U.S.C. $\$ 77 \mathrm{c}(\mathrm{a})(2)$ (1970).

142. 15 U.S.C. $\$ 80 a-3(c)(11)$ (1970).

143. See text following note 109 supra.

144. See text accompanying note 108 supra. 
such trusts under the securities laws appears to be both inconsistent with the policy and specific provisions of the $\operatorname{Code}^{145}$ and made unnecessary by these Code provisions. ${ }^{146}$

Under this public policy analysis a principal difference between retirement plans inaintained by charitable organizations and pooled incoine fund trusts is that the participants in these retirement plans are primarily motivated by an investment intent, at least when their own contributions to the plan are voluntary. Unlike the participant in a pooled income fund trust, no part of the contribution by an employee to a retirement plan maintained by a charitable institution is intended as a donation to the institution to be used in pursuing its charitable purposes. Contributions to pooled income fund trusts are motivated by more than just donative intent, however. Participants in pooled incoine funds do expect some income and tax advantages; otherwise they would simply have given the money to the charitable institution unencumbered by the reservation of an interest in the investinent proceeds of the corpus.

Except for the more manifest mvestment intent of an employee contributing to such a retirement plan, such plans appear to meet the public policy considerations identified with respect to pooled income fund trusts. Like pooled income fund trusts, such retirement plans tend not to be subject to the types of abuses against which the registration provisions of the securities laws were designed. These plans are initiated by the nonprofit charitable organization, and no profitmotivated promoters or salespersons are involved in organizing the plan or soliciting participations in the plan from employees. Thus such plans are not subject to the conflict of interest between providing benefits to annuitants and producing profits for promoters and stockholders, or commissions for salespersons, which characterizes profit-motivated companies engaged in the sale of variable annuity retirement plans.

The fact that charitable institutions are not motivated by profit can not provide a complete answer, however. Charitable organizations obviously are not free to organize any type of pooled fund designed for investment by the general public without regard to the registration requirements of the securities laws. A charitable institution that organized and operated a pooled investment account that sold variable annuity investinent contracts to the public would be subject to the registration provisions of the securities laws just as any commercial variable annuity company would. The fact that the charitable institution might use the profits from its variable annuity business to pursue its charitable purposes would not be relevant to the question of registration.

145. See text accompanying notes 123-133 supra.

146. See text accompanying notes 110-117 supra. 
Rather, when a charitable institution organizes a pooled fund to be offered to the public as an investment vehicle, the question whether registration is required should turn on whether the business of the pooled fund involves an overriding congressional policy inconsistent with registration under the securities laws. In the case of einployee retirement plans organized and niaintained by cliaritable and educational institutions, the provisions of the Internal Revenue Code express such a congressional policy. When Congress enacted section 403(b) of the Code in 1958, the Senate Fimance Committee characterized the provision as a "substitute for educational, charitable, and religious organizations for the 'qualification' [under section 401] required of industrial plans." 147 The Committee went on to note that it had provided tax benefits for section 403(b) plans beyond those found in the bill as passed by the House, because the Committee believed that "the other major benefits accorded in the case of industrial plans should also be made available to the educational, charitable, and religious organizations whose pension payments" would qualify under the House bill. ${ }^{148}$ Thus Congress appears to have indicated a policy that retirement plans for educational and charitable institutions sliould be accorded treatment at least equal to that given industrial plans.

When Congress added section 403(b) to the Code, it did not also amend section 3(a)(2) of the 1933 Act and section 3(c)(11) of the 1940 Act to expressly include within their exemptions plans that qualify under section 403(b) as well as under section 401. Registration of such plans under the securities laws, however, is clearly inconsistent with any general congressional policy that such plans be accorded equal treatment with industrial plans, whicl are exempted froin registration. And Congress in the 1970 amendinents to the 1933 Act did grant the SEC the authority to adopt rules exenipting otherwise nonexempt employee stock bonus, pension, profit-sharing or annuity plans for registration under the Act "if and to the extent the Commission determines this to be necessary or appropriate in the public interest and consistent with the protection of investors and the purposes fairly intended by the policy and provisions of this subchapter."149 The SEC has not yet exercised this authority.

Although there appears to be an expressed congressional policy in the provisions of the Code that is inconsistent with the registration

147. Senate Comm. on Finance, Report on the Technical Amendments Act of 1958, S. REP. No. 1983, 85th Cong., 2d Sess. 38 (1958).

148. Id.

149. 1933 Act, $\S 3(\mathrm{a})(2), 15$ U.S.C. $\S 77 \mathrm{c}(\mathrm{a})(2)$ (1970). See [1970] U.S. Code Cong. \& AD. News 4922. See also Security Activities of Commercial Banks: Hearings Before the Subcommittee on Securities of the Senate Committee on Banking, Housing and Urban Affairs, 94th Cong., 1st Sess. 203-04 (1975). 
of employee retirement plans of charitable and educational institutions under the securities laws, the SEC's double entity theory may operate to strip from such plans all statutory exemptions from registration. Moreover, such plans cannot safely rely on the "no action" position adopted by the SEC staff with respect to pooled income fund trusts since a primcipal factor in the staff's position was that contributors to such pooled income fund trusts were primarily motivated by a donative intent. In the case of an employee retirement plan, no part of an employee's motive in contributing to the plan is to make a gift. In light of the foregoing, and because of Congress' expressed policy to accord charitable and educational plans equal treatment with industrial plans, the SEC should exercise its power to adopt specific exemptive rules under the 1933 and 1940 Acts for employee retirement plans of charitable and educational institutions.

A rule that exempted such retirement plans from registration as investment companies would be adopted under section 6(c) of the 1940 Act. $^{150}$ Section 6(c) authorizes the SEC to grant an exemption if it finds the exemption is "necessary or appropriate in the public interest and consistent with the protection of investors and the purposes fairly intended by the policies and provisions of the Act." The SEC could grant a blanket exeniption under section 6(c) from all of the provisions of the 1940 Act since, under section 3(c)(11) of the 1940 Act, industrial plans are granted such a blanket exemption. The SEC could likewise grant an exemption from the registration requirements of section 5 of the 1933 Act to such plans, using its exemptive powers under section 3(a)(2) of the 1933 Act, since industrial plans are specifically exempted from registration by section 3(a)(2). Since a bank's single trust for fundimg a qualified industrial plan and a bank's collective trust fund for a number of industrial plans are also exempt under section 3(a) (2) of the 1933 Act and section 3(c)(11) of the 1940 Act froin registration under the Acts, the SEC's exemptive rules for charitable and educational plans could likewise cover such bank trust funds when a bank acts as trustee for charitable or educational plans. As noted earher with respect to pooled income fund trusts, however, if a bank actively participates with a charitable or educational institution in soliciting employer contributions to such a retirement plan or promotes various charitable and educational institutions to adopt such plans to be funded by the bank's collective trust fund, such activities by the bank could raise questions under the Glass-Steagall Act. ${ }^{151}$

150. 15 U.S.C. $\& 80(a)-(6)$ (1970).

151. See text accompanying notes 94-105 supra. 


\section{CONCLUSION}

This analysis of the ectoplasmic or double entity theory of an issuer, focusing primarily on the pooled incoine fund trust as a useful case study, should provide an important indication of the SEC approach to other analogous pooled "investment" vehicles organized and mamtained by exempt institutions. A study of the pooled mcome fund trust also offers a prime illustration of the interface that occurs between the Internal Revenue Code, the federal banking laws, and the securities laws because of the application of the powerful ectoplasmic theory of an issuer. That the ectoplasmic theory may be applied to, in effect, create a fictitious issuer governed by the securities laws does not mean those laws should be applied as if a more traditional issuer existed. Notwithstanding the ectoplasmic theory, both pooled income fund trusts and qualified pooled pension plans maintained by charitable and educational institutions should be exempted from the full registration requirements of the 1933 and 1940 Acts. 